Egyptian J. Anim. Prod.,Vol. 31,Supplement Issue, Nov.(1994):547-556.

\title{
ROLE OF CROSSING FINNISH LANDRACE SHEEP WITH LOCAL BREEDS ON WOOL PHYSICAL TRAITS
}

\author{
E.I. Shehata ${ }^{1}$, A.A. El Sherbiny
Aboul-Hassan \\ 1- Animal Production Research Institute, Agriculture \\ Research Center, Ministry of Agriculture, 2- Department \\ of Animal Production, Faculty of Agriculture, University \\ of Al-Azhar, Cairo, Egypt
}

\section{SUMMARY}

\footnotetext{
Targeting to evaluate changes in wool characteristics resulted of introducing Finnish Landrace (F) sheep into local breeds, 6 months growth wool produced from 7 F ewes and 20 ewes of each Ossimi (O), Rahmani (R), $1 / 2 \mathrm{~F}$ $\times 1 / 2 \mathrm{R}, 1 / 2 \mathrm{~F} \times 1 / 2 \mathrm{O}, 1 / 4 \mathrm{~F} \times 3 / 4 \mathrm{R}, 1 / 4 \mathrm{~F} \times 3 / 40$ were studied.

Finn sheep noticed to have the heaviest grease fleece weight $(2.07 \mathrm{~kg})(45$ \& more $1 / 2$ F.O, 1/2 F.R, 1/4 F.R locals), followed by then $1.56 \mathrm{~kg}$, respectively) fleece we Local $O$ and $R$ have $g$. ranged between 59.37 and $1.45 \mathrm{~kg})$. Yield percentage difference. 59.7 and 70.2 \% without any significant of flean fleece weight follow closely the trend were 150. The comparable estimates to local parents while were 141.0 and 112.48 for F, $1 / 2$ F.O and $1 / 4$ F.O $1 / 4$ F.R seems compared the Egyptian environment other locations.

Finn sheep have a wool fineness of $22.6 \mathrm{mu}$ where it seems to have some dominance in transferring this character to its crosses with local coarse wool breeds. Heterotic values were negative at all levels and types
of crossing.

Fibers length showed nearly a similar trend. Finn sheep have $8.12 \mathrm{~cm}$ fiber length which was significantly Issued by Egyptian Society of Animal Production.
} 
less than locals. Half crossbreeds were close to mid parent values while $1 / 4$ F crosses were slightly closer to the Finn short wool character. Heterosis were -11.4 and -8.5 f for $1 / 4 \mathrm{~F} . \mathrm{O}$ and $1 / 4 \mathrm{~F} . \mathrm{R}$, respectively.

Crimpness showed a different trend. Finn sheep have $6.4 \mathrm{crimps} / 2 \mathrm{~cm}$ while $O$ and $R$ have 5.6 and $4.9 \mathrm{crimps} /$ $2 \mathrm{~cm}$, respectively. Heterosis were of positive values estimated by $43.2,37.1,30.0$ and 32.5 f for $1 / 2 \mathrm{~F}$ with $O$ and $R$ and $1 / 4 \mathrm{~F}$ with $O$ and $R$, respectively.

Finn sheep have light kemp percentage (0.85\%) while free of medullated fibers. Crossing increased kemp occurrence vigorously. True wool percent inherited quite close to expected pattern. The scattered coloration characterize ossimi fleece was greatly reduced by crossing with Finn sheep.

Reywords: Sheep; Finnish landrace, wool traits

\section{INTRODUCTION}

Finnish Landrace sheep was started to be crossed with local coarse-wool fat-tailed breeds, Ossimi and Rahmani, towards increasing twinning rate and kilograms meat per ewe per year. Its role on wool performance is of importance to be evaluated either to categorize the produced wool for manufacturing purposes or to recognize its role on wool amount produced.

\section{MATERIALS AND METHODS}

The study included the collection of wool samples, from the mid-right side of seven Finn (F) ewes plus 20 ewes of each Ossimi (O), Rahmani (R), $1 / 2$ Finn $\times 1 / 2$ Rahmani (1/2 F.R), $1 / 2$ Finn $x 1 / 2$ Ossimi (1/2 F.O), $1 / 4$ $\mathrm{F} \times 3 / 4 \mathrm{R}(1 / 4 \mathrm{~F} . \mathrm{R})$ and $1 / 4 \mathrm{~F} \times 3 / 4 \mathrm{O}(1 / 4 \mathrm{~F} .0)$. Wool sheared twice yearly for 6 months growth duration. Two samples were collected for each animal, one before shearing, a staple cut from the mid right side area, and the second directly after shearing, of about $250 \mathrm{~g}$ weight from the mid right side of the fleece. Ewes ranged between 1.5 and 2.5 years old where all kept under the same management and feeding system.

The big samples were used for measuring yield percentage while stables used for measuring fiber length and diameter, crimps count and fiber types. 


\section{RESULTS AND DISCUSSION}

Fleece measurements are presented in Table 1. Finn sheep noticed to have the heaviest GFW (2.07 kg), which is 45 \% more than local breeds $(1.37$ and $1.45 \mathrm{~kg}$ for 0 and $R$, respectively). Half blood crosses were 30 and $22 \%$ more than their local parents $(1.79$ and $1.77 \mathrm{~kg}$ for $1 / 2$ F.O \& $1 / 2$ F.R, respectively). While quarter Finn crossbreeds were 14 and $13 \%$ more than their local parents, having 1.56 and $1.67 \mathrm{~kg} \mathrm{GFW}$ for $1 / 4 \mathrm{~F} . \mathrm{O}$ and $1 / 4$ F.R, respectively.

Yield percentage ranged between 59.7 and 70.28 without any recognized trend due to crossbreeding line. Finn sheep does not show significant difference in yield percentage compared to the local breeds studied.

Clean fleece weight (CFW) keep a very close trend to that recognized on GFW where their estimates compared to local parents are $150.4,130.6$ and $112.4 \%$ for Finn, $1 / 2$ F.O and $1 / 4$ F.O and $141.0,120.9$ and 113.98 for Finn, $1 / 2$ F.R and $1 / 4$ F.R, respectively.

Estimates of heterotic values (Table 3) indicate non clear trends through crossing lines. Values are not significant unless that concerning the increase in yield percentage due to introducing Finn blood at a level of $50 \%$ to Ossimi sheep (12.9\%). Similar trend was reported by Ryder and Wilon (1972) on crossbred of Finn with Merino sheep. Contrarily, Hanarhan (1974) found a decline in the GFW of the 50 and $25 \%$ Finn blood crosses with Galway sheep, which estimated by 13 and $4 \%$, respectively.

Wool production of Finnish Landrace under Egyptian environment seems to be quit higher than that measured in other locations where Donald \& Read (1967), Ryder \& Wilson (1972), Jakubec (1975), Oltenacu \& Boylan (1981), Magid et al. ( 1981 a \& b) gave estimates ranged between 2.0 and $2.86 \mathrm{~kg}$ for 12 months growth period. The relatively close value was that reported by Greef and Hofmeyr (1988) as $3.4 \mathrm{~kg}$ also for 12 months growth.

However, the 6 months growth represented in this study may be the reason of this fluctuation as it occurred during the moderate winter time of Egypt. Evaluation of wool growth over the year is needed to give full judging on the fleece growth,

Fibers characteristics are presented in Table 2. Finn sheep have fiber diameter of $22.6 \mathrm{mu}$, so it is 


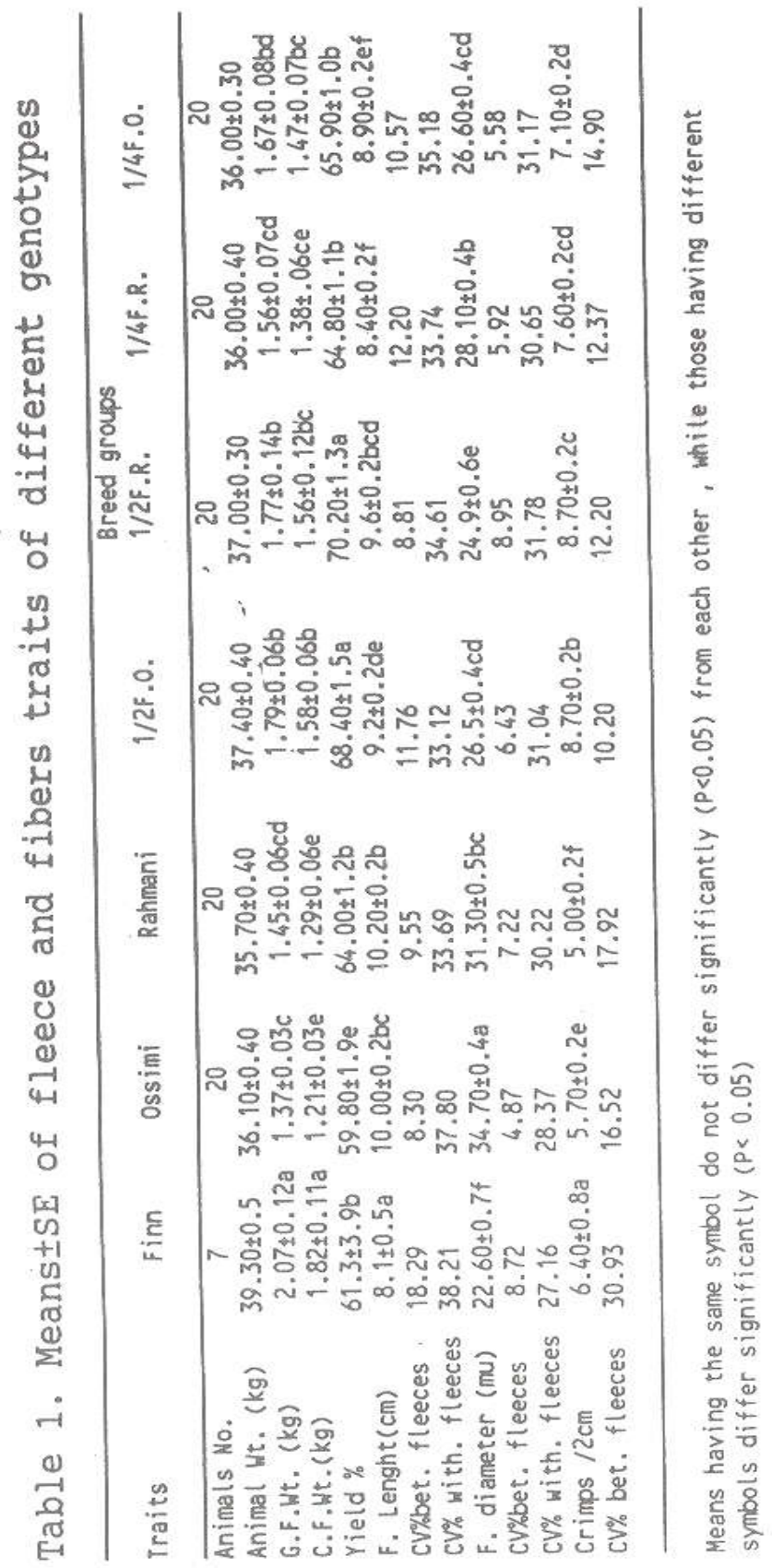




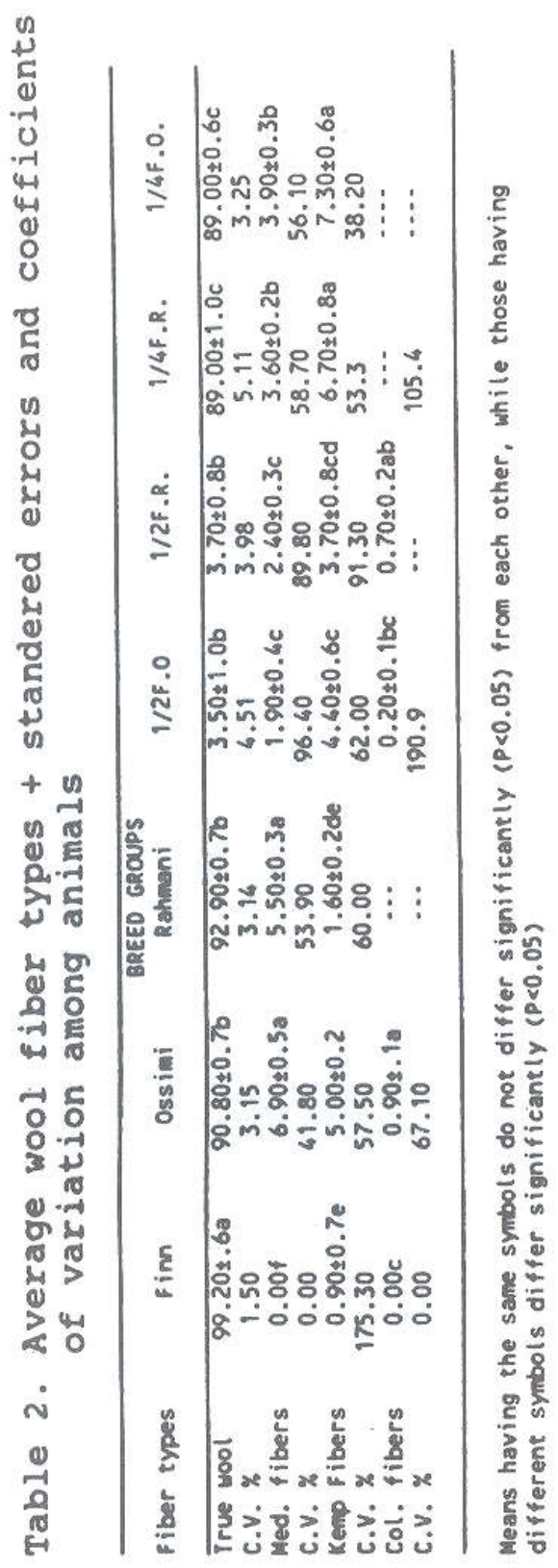


categorized among the fine wool breeds while local 0 and $R$ breeds have fiber diameter of 34.7 and $31.3 \mathrm{mu}$, respectively. The mode of inheritance of Finn fineness to the local coarse wool breeds is seemed to be of some dominance. Heterotic measurements (Table 3 ) indicates a negative values for all crossbreeds. Moreover, the share of Finn by 50 \& gave less heterotic $(-7.45$ \& for $1 / 2$ F.O \& $1 / 2$ F.R) compared to that measured when level of sharing was $258(-11.4 \&-8.5 \%$ for $1 / 4$ F.O and $1 / 4$ F.R, respectively). Fisteag et al. (1967), Dahmen et al. (1978) and Elsherbiny et al. (1979) found the same trend in fever to the fine wool parents. Meanwhile, Makled (1961), Antonova (1973), Drummaond (1978), Eseneev (1986) and Osikowski et al. (1988) found the opposite where crossbreed's fiber diameter came closer to the coarse wool parents. However, there are group of studies found that crpssbreeds attained similar to mid parent estimates (El-Sherbiny and El-Sheikh, 1969, Sidwell et. al., 1971, Ryder and wilson, 1972, Ashmawi et al., 1984 and Fahmi, 1987).

Fiber length measured in Finn sheep $(8.12 \mathrm{~cm})$ was significantly less than local breeds. Heterosis estimate in half blood crosses are negligeble where they were close to the mid parent values, while quarter Finn blood crosses indicates slight preferability towards the shortness of the Finn wool $(-11.4$ and $-8.5 \%$ for $1 / 4$ F.O \& $1 / 4$ F.R, respectively). This could be simulated as fineness of these crossbreeds are also of less values than mid parent values.

Finn crossbred with Merino gave a similar trend of similarity of fiber length to mid parent values (Ryder and Wilson, 1972), while its crosses with either Straightbred, Rambouillet or Targhee produced more fiber length than mid parent values (Sadykbekov, 1978).

Crimpness showed a different trend. Though Finn sheep have average 13.98 more crimps than locals, heterotic estimates of crossbreeds show a significant positive values estimated by $43.2 \& 37.1 \%$ for $1 / 2$ F.O \& $1 / 2$ F.R and $30.0 \& 32.58$ for $1 / 4 \mathrm{~F} . \mathrm{O}$ and $1 / 4 \mathrm{~F} . \mathrm{R}$, respectively $(P<0.05)$. Crimps count of $3 / 4$.

ossimi crossbred with Merino was also so close to Merino value while $3 / 4$ Barki with Merino was close to Barki, coarse wool breed (Shehata, 1976).

Finn fleece though being of the fine wool type, it include some kemp fibers $(0.85 \%)$ but still free of 
medullated fibers (Table 2). Big fluctuation among individuals was recognized in kemp occurrence where coefficient of variation was estimated by $175.3 \%$ among animals. Kemp was greatly increased by crossing, where $1 / 2$ Finn genotypes showed 278 and $207 \%$ heterosis values for its crosses with $O \& R$ and $1 / 4$ Finn genotypes showed $409 \& 427 \%$ values for its crosses with $O$ \& $R$, respectively. This trend is similar to that reported by Shehata (1976) on the mode of inheritance of fineness of Merino wool into local breeds.

True wool was inherited quite as expected where heterotic values are of non significant difference than mid parent values $(-1.6,-2.5,-4.2$ and -5.8 for $1 / 2$ $\mathrm{F}$ with $O \& R$ and $1 / 4 \mathrm{~F}$ with $O \& R$, respectively).

Table 3. Heterosis as percentage of expected parental weighted means

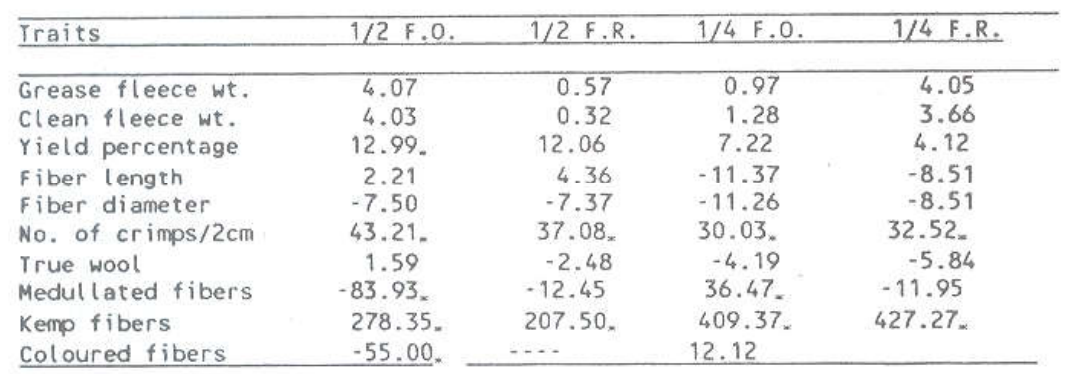

* Significant at $5 \%$ level of probability.

Percentage of coloration in Ossimi wool was significantly reduced by crossing with Finn sheep $10.0 \%$ colored wool). Heterosis measured to be of significant negative value for $1 / 2 \mathrm{~F}(-50 \%)(\mathrm{P}<0.05)$, while $1 / 4 \mathrm{~F}$ show estimate of 12.18 , but not significant (table 2).

It could be concluded that crossing with Finn sheep which mainly applied for improving prolificacy have also a positive effect on wool production where fleece weight was increased. The reduction in fiber diameter allow using wool for other products than carpets and planket since local wool commonly used for.

\section{REFERANCES}

Antonova, V., 1973. Effect of Crossbreeding on skin and wool characters in the progeny of karnobat ewes 
and Caucasian rams. Zhivotnov dni Nauki 10:75-80. (A.B.A. 42: No. 743).

Ashmawi, G., A.K. Abou-Raya and S,M, Sadek, 1984. Fleece properties of indigenous, exotic and crossbred sheep in a southern zone of the Mediterranean area. Egypt. J. Anim. Prod. 24: 206-214.

Dahmen, J.J, D.D. Hinman, J.A. Jacobs and D.O. Everson, 1978. Wool traits of Panama and Finn $x$ Panama Yearling and two-year old ewes. J. Anim. Sci. 47: $331-335$.

Donald, H.P. and J.L. Read, 1967. The performance of Finnish-Landrace sheep in Britain. J. Anim. Prod. 9: $471-476$.

Drummond, J.O., R.A. Connell and D.A. Price, 1980. Processing characteristics of Finn-cross wool. J. Anim. Sci. 50: 405-410.

Drummond, J.O, R.A. Connell and K.L. Colman, 1982. The effects of age and Finnsheep breeding on wool properties and processing characteristics. J. Anim. Sci. 54: 8-11.

El-Sherbiny, A.A.' and A.S. El-Sheikh, 1969. Physical characters of Merino and its crosses with Ossimi sheep in U.A.R., Egypt, J. Anim. Prod. 9:15-23.

El-Sherbiny, A.A. and A.S. El-Sheikh and F.M. Labban, 1969. Studies on the skin of Fleish Merino, Ossimi and their crosses in the U.A.R. Egypt. J. Anim. Prod. 11:351-360.

Eseneev, T.K., 1986. The results of crossing soviet Merino and Finnish- Landrace sheep. Zhivothovodstvo (No. 12): 41-43.

Fahmy, M.H., 1987. The accumulative effect of Finnsheep breeding in crossbreeding schemes: Wool production and leece characteristics. Canadian J. Anim. Sci. 57: $1-11$.

Fisteag, I, E. Neumann and F. Luca, 1967. Production characters of $F 1$ crossbreds of Grozeny rams with Transylvanian Merino ewes. Lucr. Stiint. Inst. agron. Timisoara Ser. Med. Vet. 10:425-436. (A.B.A. 37: No. 3649).

Greef, J. C. and J.H. Hofmeyr, 1988. Finnsheep and their utilization in crosses with the Merino under range conditions of South Africa. J. Agric. Sci. in Finland, 60: 500-504.

Hanrahan, J.P., 1974. Crossbreeding studies involving Finnish-Landrace and Galway sheep. Proc.Working 
symp. Breed Evaluation and Crossing Exp. with Farm Anim. Zeist, The Netherland. pp. 413-444.

Jahubec, V., 1975. The results of the hybridisation programme for sheep at the Unrineves Research Institute for Animal Production. Nas Chov, 35: 171-174.

Magid, A.F, V.B. Swanson, J.S. Brinks, G.E. Dickerson, J.A. Crouse and G.M. Smith, 1981a. Border Leicester and Finnsheep crosses 1- Market Lamb Production from crossbred lambs. J. Anim. Sci. 52: 1272-1279.

Magid, A.F., V.B. Swanson, J.S. Brinks, G.E. Dickerson and G.M. Smith, 1981b. Border Leicester and Finnsheep crosses. 2- Productivity of Fl ewes. J. Anim. Sci. 52: 1262-1271.

Makled, M.N.E., 1961. Improving wool production through crossing ossimi with some fine wool and medium wool breeds. M.Sc. Thesis, Cairo University, U.A.R.

Oltenacu, E.A.B. and W.J. Boylan, 1981. Productivity of burebred and crossbred Finnsheep. 2- Lamb weights and production indices of ewes. J. Anim. Sci. 52: 998-1006.

Osikowski, M.A and B. Borys, 1988. Performance of crossbreds of Polish Merino dams with Fl rams: Finn sheep $x$ Polish Merino, B- Wool Production of ewes. J. Agric. Sci. Finland, 60: 546-548.

Ryder, M.L. and D.T. Wilson, 1972. Fleece characteristics and postnatal fleece development in Finnish-Landrace $x$ Merino sheep. Anim. Prod. 15: $75-84$.

Sidwell, G.M, R.L. Wilson and F.H. Mary, 1971. Production in some purebreeds and their crosses. Effect of crossbreeding on wool production. J. Anim. Sci. 32: 1099-1102.

Sadykbekov, A.S., 1978. Wool Productionof caucasian and Finnish-Landrace $x$ caucasian sheep. zhivtnovodstvo. (No.12): $32-33$.

Shehata, E.I., 1976. Improvement of Egyptian sheep towards carpet wool by crossing with Merino sheep. M.Sc. Thesis, Al-Azhar University, Egypt.

Sidwell, G. M, R.L. Wilson and F.H. Mary, 1971. Production in some purebreeds and their crosses. Effect of crossbreeding on wool production. J. Anim. Sci. 32: 1099-1102. 


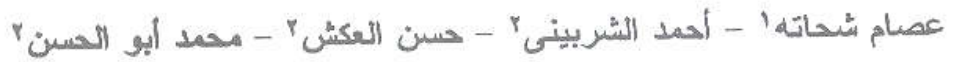
1- معهد بحوث الإنتاج الحبوانى، مركز البحوث المزر اعيه، وز اره الزر العهده.

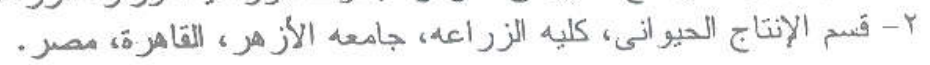

رغبه في تقيبم التغير في صفات الصوف للأغنام المحليه نتيجة للخطط مـع

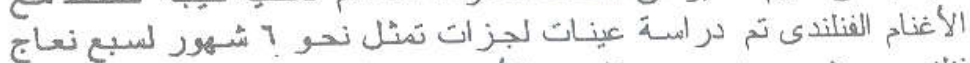

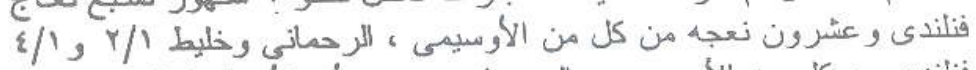

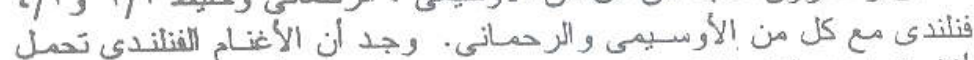

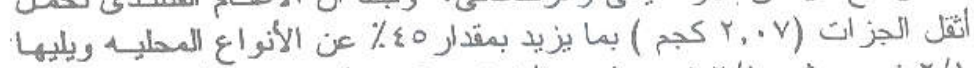

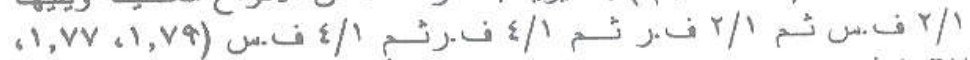

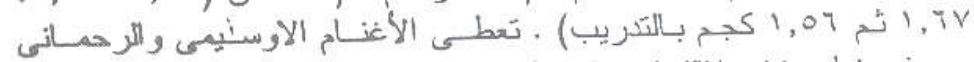

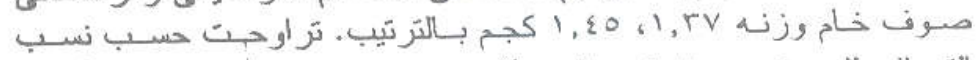

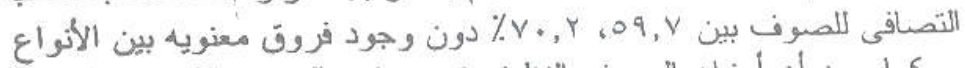

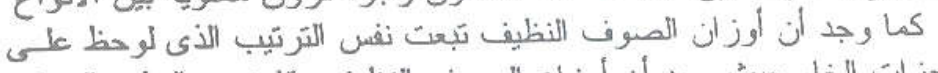

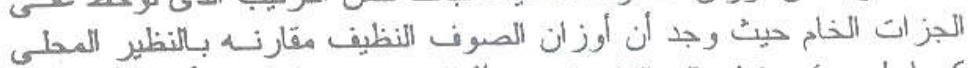

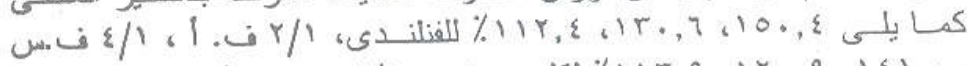

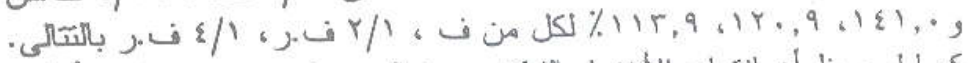

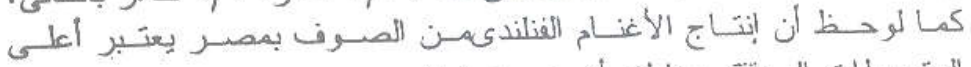

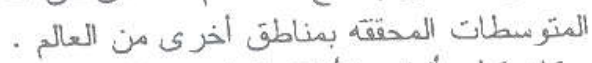

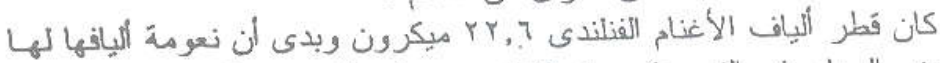

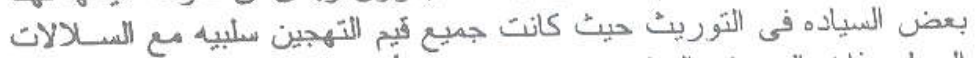

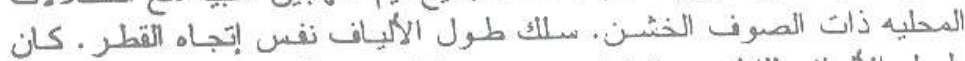

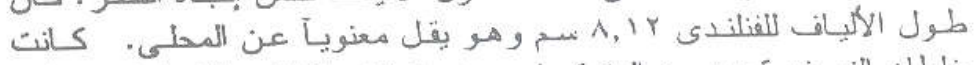

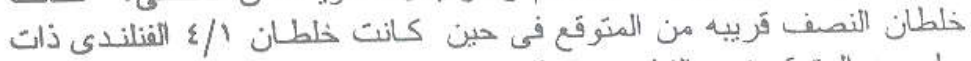

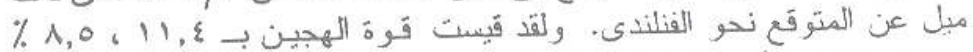

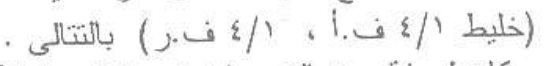
كان لصفة عدد التموجات في الليفه سلوكآ مخالفـآحيث فيمت فئ في الأنوراع

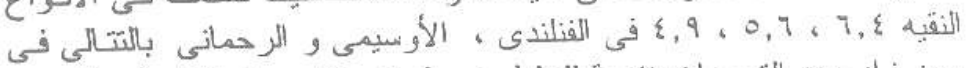

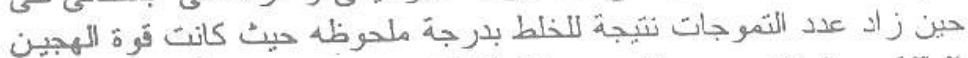

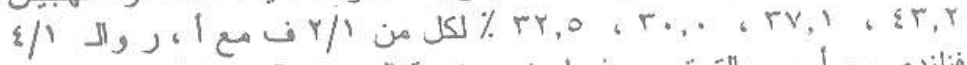

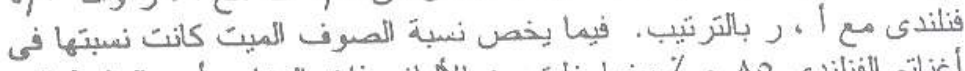

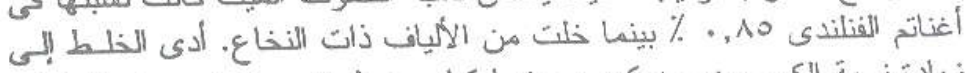

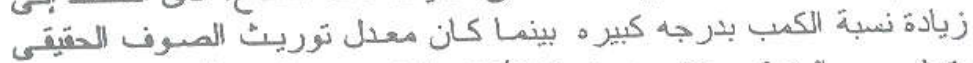
يتمّىى مع المنوقع .تتأصت نسبة الألياف الملونه بخلطان الأوسيمهى. 